\section{Artificial Lakes in Africa}

A REMARKABLE proposal for the formation of several great lakes in the interior of Africa in order to create cultivable land and stores of hydro-electric power is outlined in a report issued by Science Service, of Washington, D.C. The project emanates from $H$. Soergel, of Munich. A great dam two and a half miles long about 500 miles from the mouth of the Congo would turn the basin into an inland sea with an area of about 350,000 sq. miles. An outlet by the lower Congo would provide abundant water power or, alternatively, an outlet could be arranged to the north to create a second inland sea centring around Lake Chad, which would drain through existing wadis to the west, north-east and east by a "second Nile" to the Gulf of Gabes in the Mediterranean. This new river would provide irrigation water for vast areas in the French and Italian Sahara. A further suggestion is for a dam on the Zambezi River above Victoria Falls in order to create an inland sea over much of the Kalahari desert. Herr Soergel does not discuss the effect of evaporation on the projected Chad and Victoria Seas, both of which would lie in almost rainless regions.

\section{Bee Control in Czechoslovakia}

We learn from the Bee World that Czechoslovakia is taking drastic steps in dealing with Acarine disease. The new law insists on treatment with the recognized British or Frow remedy of all colonies within $10 \mathrm{~km}$. of an infested hive. Stocks found to be weak in midAugust are to be destroyed. The use of methyl salicylate is ordered during the spring up to honey flow, in all stocks discovered to be infested after overwintering.

\section{Indian Association for the Cultivation of Science}

INDIAN physics, under the leadership of Sir C. V. Raman and Prof. M. N. Saha, has an established position; and it is interesting to read, in its report for 1935, a history of the Indian Association for the Cultivation of Science, an institution which has played a large, if not the dominant, part in bringing about this result. The Association was founded in 1870 , and the laboratory, built in 1890 , later became an active centre of research under the stimulating guidance of Raman, who was succeeded as Mahendralal Sircar professor by Dr. K. S. Krishnan. The financial and administrative arrangements have lately been re-organized and a material annual grant obtained from the Government of India, which accordingly has a voice in the management. The work of the past year covers a fairly wide range and includes studies of molecular structure, of magnetic effects and of optical phenomena. There is, therefore, every ground for anticipating the maintenance of full activity.

\section{Anti-Rabic Treatment at Kasauli}

IN the annual report of the Pasteur Institute of India, Kasauli, for 1934, the Director states that 1,471 Europeans and 15,380 Asiatics were treated at Kasauli and associated centres, a total increase of 913 compared with 1933 . Of the treated cases, one death was reported among Europeans, and 90 among Asiatics, a mortality among the latter of 0.53 per cent, the lowest death-rate recorded during the last, ten years. In addition, 671 courses of vaccine for the prophylactic treatment of animals were issued during the year. The vaccine employed is a carbolized. 5 per cent Paris sheep vaccine.

\section{Tuberculosis and Cattle}

A FUR'THER issue of the Register of Herds attested under the Tuberculosis (Attested Herds) Schemes, England and Wales and Scotland, has been published jointly by the Ministry of Agriculture and Fisheries, 10 Whitehall Place, London, S.W.I, and the Department of Agriculture for Scotland, Queen Street, Edinburgh, 2. It contains particulars of 117 herds in England and Wales and 144 herds in Scotland which had been attested up to July 31,1936 . Since the previous issue of the Register on March 31,1936 , 36 herds have been added in England and Wales and 56 in Scotland.

\section{Parliamentary Science Committee}

LAST April the Parliamentary Science Committee received the adhesion of the Association of British Zoologists. Recently it has had the gratification of the accession of another body devoted to biology, the Association of Applied Biologists. The Committee is already strong in support from bodies devoted to applied and mechanical science, and the strengthening of the biological support was much desired. The aggregate membership of the Committee's constituent bodies is now upwards of 100,000 .

\section{International Association for Testing Materials}

The Congress of the International Association for Testing Materials is to be held in London in April next. The subjects to be discussed are divided into four groups, A (Metals), B (Inorganic Materials), C (Organic Materials), and D (Subjects of General Importance), each of which is presided over by a distinguished worker from overseas. The last Congress for Testing Materials was held in 1931, and every effort is being made to ensure that the knowledge in this most important field will be brought completely up to date. The papers will be presented in the form of summaries, so that a vast amount of information will be made available in easily accessible form. Particulars of the Congress can be obtained from the honorary secretary, Mr. K. Headlam. Morley, at the offices of the British Committee, International Association for Testing Materials, 28 Victoria Street, London, S.W.1.

\section{Announcements}

THE Right Hon. Lord Balfour of Burleigh, and Prof. John Mellanby, Waynflete professor of physiology in the University of Oxford, have been appointed members of the Medical Research Council, in succession to the Most Hon. the Marquess of 
Linlithgow, and Prof. E. D. Adrian, who retired in rotation on September 30 . The appointment of Prof. Mellanby was made after consultation with the Medical Research Council and with the president of the Royal Society. Lord Balfour has been appointed to succeed Lord Linlithgow as chairman of the Medical Research Council.

A DrNNer will be held at the Hyde Park Hotel, Knightsbridge, London, S.W.1, on November 24, at 7.30 for 8.0 p.m., when the president of the British Science Guild, the Right Hon. Lord Melchett, will preside. At the dinner, a presentation from supporters of the Guild will be made to Sir Richard Gregory, chairman of the Council of Management, in recognition of his services to science generally and to the British Science Guild in particular.

Ar a meeting of the Advisory Council of the Imperial Institute on Mineral Resources, Sir Robert Hadfield, who is a member of the Council and has been interested in the mineral work of the Institute for many years past, announced that he wished to make a contribution of $£ 1,000$ to promote the compilation of mineral brochures by the Institute. The Director accepted this generous offer with gratitude on behalf of the Board of Governors. In making this offer, Sir Robert emphasized the importance of iron and ferro-alloy metals to the Empire, and expressed a hope that this importance would be recognized in the brochure programme of the Institute.

Dr. ОтTо KNOPF, professor of astronomy at Jena since 1923 and director of the Jena Observatory since 1900, celebrated his eightieth birthday on September 24, and Prof. Wladimir Koppen of Graz, formerly head of the naval observatory at Hamburg, was ninety years of age on September 25 .

Prof. R. ZAUnICK, of Dresden, has been awarded the Sudhoff Medal by the German Society of the History of Medicine, Natural Science and Technique for his lecture on Karl Gustav Carus and his Dresden circle.

Dr. Wrumiam Hanlock Park has retired from the chair of bacteriology and preventive medicine at the University of New York after thirty-eight years service on the staff of the College of Medicine. Dr. Park is the founder of the New York City Public Health Laboratories, on which he has served for forty-two years as director.

A sPECIAL institute for experimental physiology and therapeutics has been organized at the Pirogoff military hospital, Moscow, where researches will be made in physiology, physiochemistry and biochemistry.

During the first five months of this year the number of deaths from motor accidents in New York City fell to $9 \cdot 3$ per 100,000 , which is the lowest figure hitherto reached in the towns in the United
States. In New York State the number has fallen by 14 per cent, 829 persons having been killed in comparison with 965 during the same period in 1935 .

Tete thirty-fifth Congress of the Italian Society for the Progress of Science will be held at Tripoli on November 1-7 at the same time as the meeting of the Royal Italian Geographical Society, and will constitute the first Italian Scientific Congress of the Fascist Colonial Empire. The programme will include papers on hygiene and colonial pathology, with special reference to the sanitary, prophylactic and eugenic organization of the Italian colonies. Further information can be obtained from the Segretaria generale, Societa Italiana per il progresso delle scienze, Via del Collegio 26, Rome.

THe Proceedings and Transactions of the South London Entomological and Natural History Society for 1935-36 form a record of a successful year's activities which close with the Society in a satisfactory financial condition. This publication, which appears annually, contains papers of both general and more specialized interest to naturalists, together with records of field meetings and of various congresses. The most extensive article is by Mr. Kenneth J. Hayward, and is an account of a collecting expedition along the Alto Parana, Argentina, illustrated by interesting photographs.

Applications are invited for the following appoint. ments, on or before the dates mentioned :

A chief technical instructor in the Government Trade School, Haifa-The Seeretary (SIR/CA), Board of Education, Whitehall, S.W.1 (October 26).

Three technical officers, two assistants (Grade I), and one assistant (Grade II) in the Directorate of Technical Development, Air Ministry-The Secretary, Air Ministry (S.2.D./405), Adastral House, Kingsway, W.C.2 (October 30).

Assistants (Grades I and II) in the Royal Aircraft Establishment, South Farnborough, Hants-The Chief Superintendent (October 30).

A lecturer in pathology in the University and pathologist to the Queen's Hospital, Birmingham The Secretary of the University (October 31).

A head of the Science Department, West Ham Municipal College-The Town Clerk (November 6).

A professor of applied chemistry in Andhra University-The High Commissioner for India (December 20).

A mechanical engineer, an architectural adviser and an assistant engineer to the Copper Development Association-The General Manager, Copper Development Association, Thames House, Millbank, London, S.W.1.

An assistant lecturer in education in University College, Exeter--The Registrar.

A professor of mathematics in University College, Southampton-The Registrar.

Civil engineering and architectural assistants in the drawing office of H.M. Dockyard, PortsmouthThe Civil Engineer-in-Chief, Admiralty, S.W.1. 